\title{
ANTIQUITY
}

\section{THE HUELVA HOARD (SPAIN)}

This hoard, found in 1923 at the mouth of the Rio Tinto in Andalusia, is of capital importance for chronology of the British Bronze Age. It consisted of bronze swords, spearheads, arrowheads, fibulae and miscellaneous objects. Several of the swords belong to a type common in Nw. Europe, and represented in England. The hilt is quite distinctive and is noticed at once when it occurs in English hoards, for it differs in many respects from the commoner types. The blade has a pronounced midrib, and narrows gradually to a fine point ; it was intended for thrusting rather than cutting. Examples (represented by the hilt only) have been found in England at Beachy Head, Sussex; Cumberlow Green, Herts.; Minster, Kent ; and from the Thames at Twickenham. In the British Museum are examples from the Seine at Paris ; the Boulogne, near Nantes ; the Loire, near Nantes ; and there is one also from Almeria, in SE. Spain.

The Huelva blades with a tang and rivets may be matched by English finds from the Thames at Twickenham (Bronze Age Guide, plate 2, fig. 7); from the Ouse near Ely (ib.id. fig. II); and from the Langrove hoard (Archaeologia, lxxi, plate 12, fig. 3). The type is more common in France.

Amongst the spear heads from Huelva occur some with openings in the blade. This type is well represented here, but also occurs in Northern France.

Lastly, there are arrowheads. The only example of a British Bronze Age arrowhead is that found in the Langrove hoard, where also occurred a square-socketed axe, which was either imported from France or strongly influenced by the well-known French type.

The inference is clear; at the period represented by the Huelva hoard, 'influences' from the south reached as far as England and Wales. One might go further and infer that such ' influences ' consisted of sea-borne trade ; and one might speak of a Western European region that was loosely united by the bond of trade, perhaps also by some community of culture.

But some of the Huelva bronzes point eastwards. A sword with a bronze pommel is a Balearic type; and, far more important, some fibulae-the first of the kind found in Spain - are of the same type as those found at Casibile in Sicily. These can be dated there to between 1200 and 1000 B.C. Unless therefore the British and French types represented at Huelva had a long life in those countries, during which 


\section{NOTES AND NEWS}

they remained absolutely unchanged-and this seems unlikely-we are enabled to date them in Britain, also the objects associated with them, to the period 1200-1000 B.C. Since in the Cumberlow hoard and at Beachy Head there were found winged axes, the date of these will have to be put much earlier than has previously been supposed. A full consideration of this important problem, however, would be out of place here.

Professor Bosch Gimpera has discussed the bearings of the Huelva hoard very fully in the Butlleti, to which readers are referred. It is clear that Andalusia was a region whose trade extended eastwards for an unknown distance, but (for other reasons) almost certainly as far as the Balearic Isles and Sardinia ; and northwards as far as France and probably England and Wales. The trade with Britain need not have been direct; indeed the celt from Langrove suggests indirect trade via Brittany. Huelva is only 50 miles from the mouth of the Guadalquivir, in the neighbourhood of which stood Tartessus. This great emporium was founded by the Phoenicians somewhere between I I00 and rooo B.C. ; but one is justified in assuming, as a working hypothesis at any rate, that it was already in existence then, and that it formed an entrepot for the trade of the west. Several centuries later we know (from Avienus) that the merchants of Tartessus were accustomed to trade with the Oestrymnides, which lay somewhere on the north-west coast of the Atlantic ; and trade is apt to be conservative. Huelva is an obvious outlet for the copper-mining district of the Sierra Morena ; and it would be bound to be used in the Bronze Age. We shall return to this subject later, in dealing with the problem of the glass beads found in British barrows.

Meanwhile further information may be obtained from Professor Bosch Gimpera's article "Huelva," in Ebert's Reallexikon der Vorgeschichte, which is illustrated by a full-page half-tone plate; the same writer's review of the original accounts in Butlleti de L'Associacio Catalana d'Antropologia, Etnologia, Preistoria, vol. ii, fasc. ii (I924), pp. 223-6; and the original accounts themselves published in the Boletin de la R. Academia de la Historia, vol. Ixxxiii, I923, pp. 89-9I (three plates), and in Actas y Memorias de la Sociedad Espanola de Antropologia, Etnologia y Prehistoria, vol. ii, 1923, pp. 37-40 (three figures). A short account by J. Albelda is published in Revue Archéologique, vol. xviii, 1923, pp. 222-6 (with rather inadequate line-drawings ; this reference is given incorrectly as vol. xvii by Professor Bosch Gimpera). 